Araştırma Makalesi / Research Article

\title{
RISKY SEXUAL BEHAVIOR AMONG HETEROSEXUAL MALE TURKISH UNIVERSITY STUDENTS
}

\author{
Levent KIYLIOĞLU* \\ Ali DÖNMEZ** \\ KARŞIT CINSEL ERKEK ÜNIVERSITE
ÖĞRENCİLERINDE RİSKLİ CINSEL DAVRANIŞ
}

Abstract

The aim of this study was to investigate the variables influencing risky sexual behaviors of heterosexual male Turkish university students. The sample of the study consisted of 382 university students studying at Ankara University and METU. As measurement instruments demographic questionnaire, sexual sensation seeking scale, sexual risk-taking scale, religious attitude scale, HIV knowledge scale, self-efficacy scale for AIDS prevention and Bem sex-role inventory were used. In addition to descriptive analysis, correlation and regression analyses were used. Findings showed that participants' age, having sexually transmitted infection other than HIV, getting HIV test, sexual sensation seeking level and masculinity positively predicted sexual risk taking behavior. Using condom in first intercourse, condom use self-efficacy, and the femininity negatively predicted sexual risk-taking behavior. Findings once more proved protective effect of lifelong condom use.

Keywords: HIV/AIDS, Risk-taking, Sexual Behavior.

\section{Öz}

Bu çalışmanın amacı, Türkiye'de yaşayan karşıt cinsel erkek üniversite öğrencilerinin riskli cinsel davranışlarının hangi değişkenler tarafından ve hangi oranlarda belirlendiğini ortaya koymaktır. Çalışmanın örneklemini Ankara Üniversitesi ve ODTÜ'de okuyan 382 öğrenci oluşturmuştur. Çalışmada

* Dr. Öğr. Üyesi, Zonguldak Bülent Ecevit Üniversitesi, e-posta: levent.kiylioglu@beun.edu.tr, https://orcid.org/0000-0003-2319-3805.

** Prof. Dr., Çankaya Üniversitesi, e-posta: adonmez@cankaya.edu.tr, https://orcid.org/0000-0003-3984-3534.

İntihal Taraması: Bu makale intihal taramasından geçirilmiştir.

Etik Beyan: $\mathrm{Bu}$ çalışmanın hazırlanma sürecinde bilimsel ve etik ilkelere uyulduğu ve yararlanılan tüm çalışmaların kaynakçada belirtildiği beyan olunur (Levent Kıylığlu).

Atıf: Kıylığlu. L. ve Dönmez, A. (2021), Risky Sexual Behavior Among Heterosexual Male Turkish University Students, 21(2), Abant Sosyal Bilimler Dergisi, s. 405-426, https://doi.org/10.11616/basbed.vi.901233.

Makale Gönderim Tarihi: 11.03.2021 Makale Kabul Tarihi: 17.07.2021 
demografik sorulara ek olarak cinsel heyecan arama ölçeği, cinsel risk alma ölçeği, dinsel tutum ölçeği, AIDS bilgi ölçeği, AIDS’ten korunmada öz-yeterlik ölçeği, Bem cinsiyet rolü envanteri kullanılmıştır. İstatistiksel analiz olarak betimleyici analizlerin yanı sıra korelasyon ve regresyondan yararlanılmıştır. Yaş, cinsel yolla AIDS dışında başka bir hastalığa maruz kalma ve AIDS testi olma değişkenleri cinsel risk alma davranışını olumlu yönde ve anlamlı olarak yordamıştır. Cinsel heyecan arama ve erkeksilik cinsel riski olumlu ve anlamlı olarak yordayan diğer değişkenlerdir. İlk ilişkide kondom kullanma, AIDS’ten korunmada kondom kullanma öz-yeterliği ve kadınsılı̆̆ın cinsel risk alma davranışını olumsuz yönde ve anlamlı olarak yordadığı belirlenmiştir. Çalışmanın bulguları yaşam boyu kondom kullanmanın koruyuculuğunu bir defa daha ispatlamıştır.

Anahtar Kelimeler: HIV/AIDS, Risk Alma, Cinsel Davranış.

\section{Introduction}

As in some other countries in the world, HIV (Human Immunodeficiency Virus) has started to become a significant issue in Turkey. In Turkey, there are 22,345 HIV-positive people and 1864 AIDS (Acquired Immune Deficiency Syndrome) cases, whose confirmation test has been determined positively from 1985 when the first case was seen, until 10 November $2019.80 .4 \%$ of the cases were men, $19.6 \%$ were women and $15.5 \%$ were foreign nationals. The age group with the highest number of cases is the 25-29 and 30-34 age group (The Ministry of Health of Turkey, 2019). Due to the problems in the monitoring system and health information network, official figures disclosed in the country on HIV/AIDS do not reflect the actual number of people living with the infection (Acaroğlu, 2007: 49). It is estimated that the real number of people living with HIV/AIDS is much more than the official figure.

While HIV can be transmitted through blood transfusion, sexual transmission is much more common in Turkey and many countries of the world. The purpose of this study was to bring out psychological and social variables associated with the risky sexual behavior of Turkish heterosexual male university students. Although university students in Turkey being at risk, there is a limited number of studies on sexual and risky sexual behavior associated with them (Avc1kurt, 2014; Siyez \& Siyez, 2009). Studies focusing on sexual behavior can help to better understand the unhealthy behavior of young people. Risky sexual behavior was defined in this study according to highly cited variables in the literature, that is; anal sex, one-night stand, sex without condoms, sex with older persons, concurrent sexual relationship, using alcohol and illegal drugs before or during intercourse, starting sex at an early age, and sex with lots of people (Cooper, 2002; Kiylığlu \& Dönmez, 2017; Leigh \& Stall, 1993; Norton et al., 2005; Stulhofer et al., 2009: 216). 
University students are one of the most vulnerable groups in society and young people are developmentally prone to take risks. In many countries, university students' sexual behaviors and risky sexual behaviors have been studied in detail. On the other hand, studies on the sexual and risky sexual behaviors of students in Turkey have been very limited in number. This study is one of the first studies that explore sexual risk-taking behavior and the factors associated with this behavior among heterosexual male university students in Turkey. Studies that reveal the prevalence of risky sexual behaviors and the psychological variables associated with these sexual behaviors can help reduce the sexual risk- taking in the society.

In this study, a couple of theories and perspectives were used to explain independent variables. These independent variables are the psychological and social variables used in this study, which are predicted to be associated with sexual risk-taking behavior of the participants. Religious attitudes and gender roles of the participants have been explained by social-cultural perspectives. On the other hand, respondents HIV/AIDS knowledge explained by cognitive decision making, sexual sensation seeking by trait theories, and finally self-efficacy for AIDS prevention by social-cognitive perspective (Kıylığlu \& Dönmez, 2016). Considering HIV/AIDS risk knowledge, which is one of the main variables that we think predicts risky sexual behaviors, it is expected that those who have sufficient knowledge about the transmission routes of HIV should avoid sexual intercourse under the influence of alcohol and drugs, anal sex and one-night stands. The research findings obtained using these theoretical approaches are summarized below.

The social-cultural perspective assumes that individuals' risk-taking behaviors are largely shaped by the social-cultural context they live in, the social pressure they experience, and the cultural beliefs and attitudes of the society. Social-cultural theory developed by Vygotsky stated that other people and their social rules have the greatest impact on people's behavior, thought processes, and emotions (Vygotsky, 1978). One research investigating the relationships between alcohol use, sexual behavior, and religiosity (Moore et al., 2013: 938), has shown that religious beliefs reduce alcohol use and sexual risk among university students. Another study conducted with adolescents (Neymotin \& Downing-Matibag, 2013: 565), found that religious adolescents were more difficult to give up on risky sexual behavior, although they can be discouraged more easily from drug use. Some studies were also found a negative association between adolescent sexual activity and family religiosity (Landor et al., 2011; Manlove et al., 2008). Because of the norms of masculinity and femininity learned through socialization, men are more prone to sexual risk-taking 
(Harrison et al., 2006). One study has been shown that young men are much more likely to have sexual intercourse with more than one person than women (O'Sullivan et al., 2006). Another study has been shown that men who place a high value on being perceived as masculine appear to be at greater risk for sexually transmitted diseases (Reidy et al., 2016: 463).

According to cognitive decision making model, decision making is always rational and planned behavior. Those who have sufficient knowledge about HIV/AIDS are expected to avoid risky sexual behavior. If this is so, people who have sufficient knowledge about HIV infection and prevention are expected to use condoms regularly in sexual intercourse, avoid anal and concurrent sexual practices. However, studies investigating the relationship between HIV/AIDS knowledge and risky sexual behavior have difficulty in finding a strong link between these variables. To give an example of the studies on this subject, the effect of information on HIV/AIDS on the sexual practices of sex workers was not found significant in Brazil (Patricio et al., 2019). Similarly, multicomponent communitybased intervention study in Zimbabwe found lack of relationship between HIV knowledge and HIV risk of the participants (Yau et al., 2020). These findings could show that individuals do not act rationally and in a planned manner in their sexual relations.

Personality traits are manifested in consistent thoughts, feelings, and behaviors. As a personality trait, sensation seeking was defined by Zuckerman (2007) as seeking diverse, new, complex, intense excitement and experiences, willingness to take physical, social, legal, and monetary risks for such experiences. Sexual sensation seeking has been accepted as a personality trait and is associated with risk-taking behavior (Zuckerman, 2007). Zuckerman (2007: 158) found that pre-marital sensation seeking was associated with three types of risky sexual behaviors, including sexuality with more than one person, sex without a condom, and sexuality with strangers, and determined that the risk increased with the use of drugs and alcohol before and during intercourse. In addition, Zuckerman (2007: 154) also highlighted that sexual sensation seeking is higher in men than in women. Similarly, the overall sensation seeking level of male college students was found to be higher than the sensation seeking level of female students in a study conducted in Turkey (Öngen, 2007: 116). In another study, higher sexual sensation seeking was associated with more vaginal and anal sex partners in the USA (Nguyen et al., 2012: 1237).

The social-cognitive theory developed by Bandura claims that the individual is not passively controlled by his environment; on the contrary, person actively interacts with his/her environment and shapes it. Selfefficacy theory claims that people's confidence in their skills is the most 
important factor determining success. Individuals with high levels of selfefficacy tend to perceive the challenges they face as exciting opportunities to test and develop their own abilities (Gallagher, 2012: 316). In measuring the relationship of self-efficacy with risky sexual behavior, self-efficacy for AIDS prevention scales were generally used. In a study conducted on 743 Taiwanese adolescents aged 16-18 (Lee et al., 2009: 658), which investigated the relationship between self-efficacy for AIDS prevention and risky sexual behavior, it was found that those with high self-efficacy in protection from AIDS displayed risky sexual behavior at a lower rate. In another study among university students in Nigeria, which searched the condom use self-efficacy, parental support was found to be associated with higher partner communication efficacy for condom use (Ajayi \& Olamijuwon, 2019: 13).

On the basis of the current HIV/AIDS literature we hypothesized that selfefficacy for AIDS protection, HIV/AIDS risk knowledge, religiosity, sexual sensation seeking, gender roles and some socio-demographic variables predict risky sexual behavior significantly in heterosexual male Turkish university students.

\section{Methods}

\subsection{Participants}

A questionnaire was conducted with 495 unmarried, sexually active, heterosexual, and male university students, namely Middle East Technical University (METU) and Ankara University students, using the convenience sampling technique. However, a hundred and thirteen voluntary participants provided incomplete (missing more than two items on one or more measures) data, being sexually inactive or married, analyses were included data from 382 university students. The sample was only heterosexual males and ranged in age from 18-25 years, with a mean age of $22(S D=1.82)$. The respondents spent on average four years at their universities. While the majority of the participants studying in the science field (85\%), a small part of them stated that they study social sciences (13\%). Before starting university education in Ankara, 55\% of them have lived in big cities, $32 \%$ in other cities, and $12 \%$ in small districts in Turkey. Forty-five percent of the participating students were staying with their families, $24 \%$ in dormitories, and $17 \%$ live with relatives, and $11 \%$ of them said to live alone at home. 


\subsection{Materials}

Survey instruments that were used in this study included index of sexual risk taking, sexual sensation seeking scale, religious attitude scale, selfefficacy scale for AIDS prevention, HIV knowledge questionnaire, Bem sex role inventory, and some demographic questions. These scales are briefly introduced below.

Index of Sexual Risk-Taking (ISRT): The ISRT (Stulhofer et al., 2009: 216) is a 10 item, self-report scale that assesses the risky sexual behavior of a person who experiences it in the last 12 months and his whole life. In scale development, the ISRT scale had a 0-10 range, with higher scores reflecting more sexual risks. Cronbach's alpha for ISRT was .64 (Stulhofer et al., 2009: 216). For the Turkish adaptation study of the ISRT, data were collected from heterosexual university students (Kıylığlu, 2013). Cronbach's alpha score of ISRT for the Turkish study was found as .71, split-half reliability as .68 , and mean sexual risk score as 3.31. A t-test was carried out to ascertain whether the adopted ISRT discriminated between participants who had been diagnosed with sexually transmitted illnesses (STI) and those who had not, significant differences were found and in the expected directions. That means participants with past STI diagnoses scored higher on ISRT (Kiylioğlu, 2013). In this study Cronbach's alpha score of the scale was found as .68.

Sexual Sensation Seeking Scale (SSSS): The SSSS is an 11 item self-report scale that corresponded to an attraction toward a range of sexual practices, including increased frequencies of unprotected sexual intercourse and a greater number of sexual partners. It was developed by Kalichman and Rompa (1995) in order to predict HIV risk behavior of gay men and heterosexual persons, and included items from Zuckerman and colleagues' Sensation Seeking Scale reflecting sexually relevant themes. For the Turkish adaptation of the SSSS that used 4-point Likert- format ranging from 1 (not like me) to 4 (like me), data were collected from heterosexual university students (Kıylığlu, 2013), and Cronbach's alpha found as .83. An item of "My sexual partners probably think I am a risk-taker" was not strongly associated with the rest of the scale. Therefore it was removed from the scale and Cronbach's alpha score for 10 item scale increased to .84 (Kiylığlu, 2013). In this study Cronbach's alpha score of the SSSS was calculated as .77 .

Religious Attitude Scale (RAS): The RAS measures religious attitudes in an Islamic tradition, consist of 8 item self-report scale, uses a 5-point Likert-format, ranging from 1 (completely disagree) to 5 (completely agree), and it is scored by computing the mean endorsement (total 
score/number of items). It was developed by Ok (2011), and Cronbach's alpha scores of the scale was recorded between .81 and .91 . In this study Cronbach's alpha score of the RAS was calculated as .93.

Self-Efficacy Scale for AIDS Prevention (SEA): SEA was developed by Lopez and Rubia (2001), consist of 27 items self-report scale, uses a 5point Likert-format, ranging from 1 (I am not sure) to 5 (I am completely sure) and scored by computing the mean endorsement. Individuals with high self-efficacy for AIDS prevention are expected to be more likely to avoid risky sexual behavior. The original scale consists of four subcomponents and aims to measure the following skills: Ability to use condom (SEA condom use), ability to say no to sexual intercourse (SEA refuse), ability to ask one's sexual partner about previous sexual relationships (SEA questions), and family related behavior of the participants (SEA family) (Lopez \& Rubia, 2001). For the Turkish adaptation of the SEA, data were collected from university students (Bulduk \& Erdoğan, 2008). Cronbach's alpha score of the 27 item Turkish SEA was found as .93. The self-efficacy score was found to be significantly higher for those studying in health sciences, those who were not sexually active, and for the female students. In the Turkish adaptation study, psychometric analysis supported the reliability and validity of the SEA and its four subscales (Bulduk \& Erdogan, 2008). In this study, Cronbach's alpha of one subscale that assesses "family related behavior of the participants" was found as .34 and removed from the scale. Internal consistency of the other three sub-scales of the SEA was found between .79 and .85 .

HIV Knowledge Questionnaire (HIV-KQ): It was developed by Carey and Schroder (2002), an 18 item self-report measure of HIV-related knowledge. The HIV-KQ consists of statements about the ways of transmission of HIV, and prevention from the disease. Participant response to the scale items with "yes", "no", or "I do not know", and true answer get a score, "false" and "I do not know" responses get no point. Analyses were found Cronbach's alpha scores of the HIV-KQ across samples between .75 and .89. The scale was adapted to Turkish by Bulduk (2009), and an item to total correlation of the Turkish HIV-KQ was found between .24 and .57. Cronbach's alpha of the scale was found as .85 and test retest stability of the Turkish HIV-KQ was found as .80 (Bulduk, 2009). In this study Cronbach's alpha score of the HIV-KQ was calculated as .73.

Bem Sex Role Inventory (BSRI): The scale was developed by Bem (1974) that has 60 items self-report scale, and uses a 7-point Likert- format, ranging from 1 (not at all desirable) to 7 (extremely desirable). The scale was adapted to Turkish by Kavuncu (1987), and total items of the scale had 
been reduced to 40 (Dökmen, 1999). Scale items such as loyalty and softness indicate femininity, while dominance, assertiveness and idealism indicate masculine gender roles. Androgen means showing both feminine and masculine features, while unidentified gender role refers to showing neither. In order to determine the gender roles of the participants, the total scores or average scores of the scale items indicating femininity and masculinity are calculated. Considering the masculinity and femininity score medians of the sample, each participant is placed in one of four different groups, such as feminine, masculine, androgen, or unidentified, depending on whether they are above or below the masculinity and femininity median (Dökmen, 1999). Turkish BSRI test-retest stability for Femininity Scale was found as 0.75 , for Masculinity Scale as 0.89. Cronbach's alpha coefficients were found 0.73 for Femininity Scale and 0.75 for Masculinity Scale (Dökmen, 1999: 34). In this study, internal consistency of the BSRI for Femininity Scale was found as .79, and for Masculinity Scale as .84.

Demographic Characteristics: These variables included age, monthly income, education (years), education field, place of residence at the university, previous settlement, sexual orientation, condom use at first intercourse, planning status of first intercourse, HIV testing status, having sexually transmitted diseases (STD) other than HIV/AIDS such as syphilis or hepatitis, and current relationship status.

\subsection{Procedure}

Before data collection, research permission was received from two state universities' ethics committee. Data were collected from healthy and voluntary university students from October 2013 to October 2014. Students were requested to answer to the questionnaire by using paper and pencil. Some money was given as a bonus to those who wish and some of the participants were completely voluntary. Participation took between 2530 minutes at the university campuses located in Ankara, and then participants received feedback on the application.

\section{4. Analyses}

In the first place, a descriptive analysis of survey instruments was made by using IBM Statistical Package for the Social Sciences (SPSS version 15). Risky sexual behaviors of the participants were given by using percentages. Using the independent sample t-test, some of the associations between sexual risk-taking and demographic questions were revealed. Afterwards, a Pearson correlational analysis between sexual risk-taking behavior, predictor variables and demographic questions was carried out. In the final stage of the analysis, we applied multiple regression analysis 
to assess the relative effects of predictor and demographic variables over sexual risk-taking behavior. Forced entry method was chosen in multiple regression analysis.

\section{Results}

\subsection{Descriptive findings}

In the first place, risky sexual behaviors of the respondents were given as percentages. Before sexual intercourse, the majority of the participants (77.7\%) used alcohol frequently. More than half of them (57.6\%) experienced one-night stand in the last 12 months. $40 \%$ of the respondents had anal intercourse at least once in all life. Forty-three percent of the participants reported not using a condom in the last 12 months, and thirtyeight percent of them in the last intercourse. Thirty-eight of the respondents reported having experience of concurrent sexual relationships. Mean number of the sexual partner of the respondents were 5 persons in all life. Using illicit drugs before sex (23\%), starting intercourse earlier than 16 years old (17.8\%), and having sex with a partner 10 or more years older in the last 12 months $(11 \%)$ were reported fewer compared to the other risky sexual behavior.

More than half of the participants (64\%) used condom at first intercourse and half of them $(50.8 \%)$ planned their first sexual act. Most of them $(91.4 \%)$ had no idea about their HIV status, very few of them $(8.4 \%)$ had tested for HIV, and only one participant reported having HIV infection. Very few of them (3.4\%) reported STD other than HIV. A sizeable proportion of the participants' gender roles were found to be androgen $(30.3 \%, n=116)$, and unidentified $(28 \%, n=107)$. Feminine $(21.2 \%, n=$ $81)$ and masculine $(20.4 \%, n=78)$ gender roles were seen relatively at a lower rate. Risky sexual behavior differed significantly by gender roles and was found $F(3,378)=5.25, p=.05$. We applied Tukey analysis in order to identify between which groups the difference arise. Masculine participants had more sexual risk $(M=4.71, S D=2.34)$ than unidentified $(M=3.63, S D=2.2)$ and feminine $(M=3.38, S D=2.2),(p=.008 ; p=$ $.001)$ respondents.

By using the independent sample t-test, some of the relationships between sexual risk-taking and demographic questions were uncovered. The difference between sexual risk-taking scores of the participants who used condom at first intercourse $(M=3.41, S D=2.2)$ and who did not use $(M=$ $4.73, S D=2.25$ ) found to be significant $t(378)=-5.57, p=.001$. Similarly, the participants who planned their first sexual act $(M=3.62, S D=2.2)$ took significantly less sexual risk than participants who did not plan it $(M=$ 
4.17, $S D=2.37), t(379)=-2.35, p=.05$. Also, the participants who were tested for HIV $(M=5.5, S D=2.29)$ had higher sexual risk scores than those who were not tested $(M=3.75, S D=2.25), t(379)=4.24, p=.001$. Similarly, the participants who had STD other than HIV took more sexual risk $(M=5.31, S D=2.95)$ than those who had no STD $(M=3.83, S D=$ $2.26), t(380)=2.29, p=.05$. Descriptive results of the survey instruments were presented in Table 1.

\subsection{Correlates and predictors of risky sexual behavior}

In this part of the study, first Pearson correlational analyses between

Table 1: Descriptive Results of the Survey Instruments $(n=382)$

\begin{tabular}{|l|c|c|c|c|}
\hline & $\begin{array}{c}\text { Mean } \\
\text { (SD) }\end{array}$ & $\begin{array}{c}\text { Observed } \\
\text { min./max. }\end{array}$ & $\begin{array}{c}\text { Potential } \\
\text { min./max. }\end{array}$ & $\begin{array}{c}\text { Cronbach's } \\
\text { Alpha }\end{array}$ \\
\hline Predictor Variables & $10.3(3.0)$ & $2-17$ & $0-18$ & 0.73 \\
\hline HIV-KQ & $80.8(14.5)$ & $43-127$ & $27-135$ & 0.82 \\
\hline SEA & $27.5(9.5)$ & $11-55$ & $11-55$ & 0.85 \\
\hline SEA refuse & $28.9(6.5)$ & $8-40$ & $8-40$ & 0.82 \\
\hline SEA condom use & $16.4(3.7)$ & $4-20$ & $4-20$ & 0.79 \\
\hline SEA questions & $20.2(8.9)$ & $8-40$ & $8-40$ & 0.93 \\
\hline RAS & $27.0(5.2)$ & $12-39$ & $10-40$ & 0.77 \\
\hline SSSS & $203.2(22.5)$ & $92-254$ & $40-280$ & 0.85 \\
\hline BSRI & $98.9(13.4)$ & $43-130$ & $20-140$ & 0.79 \\
\hline BSRI femininity & $104.3(14.6)$ & $49-134$ & $20-140$ & 0.84 \\
\hline BSRI masculinity & \multicolumn{5}{|c|}{ Presumed Outcome Variable } \\
\hline \multicolumn{7}{|c|}{$3.88(2.3)$} & $0-10$ & $0-10$ & 0.68 \\
\hline ISRT &
\end{tabular}

Note: HIV-KQ = HIV knowledge questionnaire; SEA = self-efficacy scale for AIDS prevention; SEA refuse = self-efficacy of refusing sexual intercourse; SEA condom use $=$ self-efficacy of condom use; SEA questions = self-efficacy of questioning potential partner; RAS = religious attitudes scale; SSSS = sexual sensation seeking scale; BSRI $=$ Bem sex role inventory; BSRI femininity $=$ Bem sex role inventory for femininity; BSRI masculinity $=$ Bem sex role inventory for masculinity; ISRT = index of sexual risk-taking.

presumed outcome variable, predictor variables and demographic questions was carried out. Then we applied multiple regression analysis to assess the relative effects of predictor and demographic variables over sexual risk-taking behavior.

As a result of the correlation analysis, only one sub-scale of BSRI was associated with the presumed outcome variable. It was found a positive significant correlation between masculinity and risky sexual behavior. That means, when the respondents masculinity level increase, they tend 
Table 2: Pearson Correlations Among Predictor Variables and Presumed Outcome Variable (ISRT)

\begin{tabular}{|c|c|c|c|c|c|c|c|c|c|c|c|c|c|c|c|}
\hline Variables & 1 & 2 & 3 & 4 & 5 & 6 & 7 & 8 & 9 & 10 & 11 & 12 & 13 & 14 & 15 \\
\hline 1.Age & 1.00 & & & & & & & & & & & & & & \\
\hline 2.Income & $0.14 * *$ & 1.00 & & & & & & & & & & & & & \\
\hline 3.STI & -0.09 & 0.01 & 1.00 & & & & & & & & & & & & \\
\hline 4.Condom use & $0.11 *$ & 0.04 & 0.05 & 1.00 & & & & & & & & & & & \\
\hline 5.Planning status & -0.03 & 0.08 & 0.07 & $0.21 * *$ & 1.00 & & & & & & & & & & \\
\hline 6.HIV test & $-0.17 * *$ & 0.06 & -0.01 & -0.03 & -0.06 & 1.00 & & & & & & & & & \\
\hline 7.SEA refuse & 0.02 & 0.05 & 0.08 & 0.03 & 0.05 & 0.01 & 1.00 & & & & & & & & \\
\hline 8.SEA condom use & -0.09 & -0.04 & 0.04 & $0.38 * *$ & -0.09 & 0.05 & $0.22 * *$ & 1.00 & & & & & & & \\
\hline 9.SEA questions & 0.01 & 0.07 & -0.05 & -0.01 & 0.07 & 0.06 & 0.08 & $0.25 * *$ & 1.00 & & & & & & \\
\hline 10.HIV-KQ & -0.03 & 0.08 & 0.01 & -0.05 & -0.01 & -0.06 & -0.05 & 0.10 & $0.11 *$ & 1.00 & & & & & \\
\hline 11.RAS & $0.13 *$ & -0.03 & -0.02 & 0.05 & -0.06 & 0.06 & $0.22 * *$ & 0.03 & -0.02 & $-0.19 * *$ & 1.00 & & & & \\
\hline 12.SSSS & -0.01 & -0.04 & -0.07 & -0.09 & -0.05 & -0.08 & $-0.37 * *$ & $-0.18 * *$ & -0.02 & $0.12 *$ & -0.05 & 1.00 & & & \\
\hline 13.BSRI femininity & $0.11 *$ & 0.03 & -0.03 & 0.02 & -0.08 & -0.08 & $0.14 * *$ & 0.09 & 0.09 & -0.01 & $0.29 * *$ & $0.12 *$ & 1.00 & & \\
\hline 14.BSRI masculinity & $0.12 *$ & -0.03 & -0.06 & 0.02 & -0.07 & -0.03 & $0.16 * *$ & 0.01 & 0.05 & 0.06 & $0.25 * *$ & 0.07 & $0.29 * *$ & 1.00 & \\
\hline 15.ISRT & $0.11 *$ & -0.08 & $0.12 *$ & $-0.26 * *$ & $-0.12 *$ & $0.21 * *$ & $-0.17 * *$ & $-0.27 * *$ & 0.01 & -0.03 & \begin{tabular}{l|l}
0.01 & \\
\end{tabular} & $0.31 * *$ & $\mid-0.09$ & $0.18 * *$ & 1.00 \\
\hline
\end{tabular}

\section{$* p<0.05 ; * * \mathbf{p}<0.01$}

Note: STI = status of STI other than HIV/AIDS; condom use = condom use at first intercourse; planning status = planning status of first intercourse; HIV test = HIV test status; SEA refuse = self-efficacy of refusing sexual intercourse; SEA condom use $=$ self-efficacy of condom use; SEA questions = self-efficacy of questioning potential partner; HIV-KQ = HIV knowledge questionnaire; RAS = religious attitudes scale; SSSS = sexual sensation seeking scale; BSRI femininity = Bem sex role inventory for femininity; BSRI masculinity = Bem sex role inventory for masculinity; ISRT = index of sexual risk-taking. 
to have more sexual risk. Two sub-scales of SEA, those are refusing sexual intercourse and condom use self-efficacy correlated significantly and negatively with risky sexual behaviour. That is, self-efficacy for refusing sexual intercourse and condom use self-efficacy were protective against risky sexual intercourse. SSSS also positively and moderately correlated with sexual risk-taking behaviour. When respondents sexual sensation seeking level increase, their risky sexual behaviour go up or vice versa. However, the other two main predictor variables, RAS and HIV-KQ were not related to the main outcome variable. It was not found any significant correlation between risky sexual behavior and given two main predictor variables. Some of the demographic variables were also related to sexual risk-taking behavior. Participants' age, having STD other than HIV, getting HIV test correlated with sexual risk-taking behavior positively. On the other hand, condom use in first intercourse correlated with sexual risktaking behavior negatively. Pearson correlation analysis results were presented in Table 2.

To assess the relative effects of demographic variables and predictor variables such as gender roles, self-efficacy, sexual sensation seeking, religious attitudes, and HIV knowledge, we carried out multiple regression analysis using ISRT score as the dependent variable. Analyses were done by using the forced entry method. First, demographic variables like age and income entered to regression, and the stage explained only $2 \%$ of the variation on sexual risk-taking behaviour. $\mathrm{R}^{2}=.02, F(2,379)=4.317, p=$ .05 .

In the second step, condom use on first intercourse, planning status of first intercourse, ever having HIV test, and having STD other than HIV demographic questions entered to regression. $\mathrm{R}^{2}=.14, F(6,375)=13.227$, $p=.001$. The change in the variance explained is significant, $\Delta \mathrm{R}^{2}=.12$, $F(4,375)=13.227, p=.001$.

In the third step, all of the predictor variables, those are the sexual sensation seeking scale, religious attitude scale, three sub-scales of self-efficacy scale for AIDS prevention, HIV knowledge questionnaire, and two subscales of Bem sex role inventory entered to regression. $\mathrm{R}^{2}=.28, F(14,367)$ $=9.019, p=.001$. The change in the variance explained is significant, $\Delta \mathrm{R}^{2}$ $=.14, F(8,367)=9.019, p=.001$. Overall the model explained $28 \%$ of the variation on sexual risk-taking behavior. This explained value is a mediumsized variance.

In brief, results showed that participants' age, having STD other than HIV, getting HIV test predicted sexual risk-taking behavior positively. Sexual sensation seeking scale and masculinity sub-scale scores of the Bem sex- 
role inventory also predicted sexual risk-taking behavior positively. Using a condom in first intercourse, condom use self-efficacy scores of selfefficacy scale for AIDS prevention, and the femininity sub-scale of the Bem sex-role inventory predicted sexual risk-taking behavior negatively. HIV knowledge level and religious attitudes did not predict sexual risktaking behavior significantly. These variables were not associated with sexual risk-taking behavior of heterosexual male Turkish university students. Multiple regression analysis results were also presented in Table 3.

Table 3: Multiple Regression of the Predictor Variables over Sexual Risk Taking $(n=382)$

\begin{tabular}{|l|c|c|c|c|}
\hline Predictor variables & $\mathrm{b}$ & $\beta$ & $\mathrm{t}$ & $\mathrm{p}$ \\
\hline 1.Step & 0.16 & 0.13 & 2.45 & 0.015 \\
\hline Age & -0.37 & -0.10 & -1.95 & 0.052 \\
\hline Income & 1.63 & 0.13 & 2.67 & 0.008 \\
\hline 2.Step & -1.16 & -0.24 & -4.96 & 0.000 \\
\hline STI & -0.35 & -0.08 & -1.53 & -0.127 \\
\hline Condom use & 1.57 & 0.19 & 3.88 & 0.000 \\
\hline Planning status & \multicolumn{4}{|l|}{} \\
\hline HIV test & -0.02 & -0.08 & -1.47 & 0.141 \\
\hline 3.Step & -0.06 & -0.17 & -3.29 & 0.001 \\
\hline SEA refuse & 0.03 & 0.05 & 1.16 & 0.248 \\
\hline SEA condom use & -0.03 & -0.04 & -0.89 & 0.376 \\
\hline SEA questions & -0.01 & -0.02 & -0.38 & 0.713 \\
\hline HIV-KQ & 0.09 & 0.20 & 4.14 & 0.000 \\
\hline RAS & 0.03 & 0.20 & 4.18 & 0.000 \\
\hline SSSS & -0.02 & -0.19 & -2.89 & 0.004 \\
\hline BRCI masculinity
\end{tabular}

Note: STI = status of STI other than HIV/AIDS; condom use = condom use at first intercourse; planning status = planning status of first intercourse; HIV test $=$ HIV test status; SEA refuse = self-efficacy of refusing sexual intercourse; SEA condom use $=$ self-efficacy of condom use; SEA questions = self-efficacy of questioning potential partner; HIV-KQ = HIV knowledge questionnaire; RAS = religious attitudes scale; SSSS = sexual sensation seeking scale; BSRI masculinity = Bem sex role inventory for masculinity; BSRI femininity = Bem sex role inventory for femininity.

\section{Discussion}

This study is one of the first studies that explore sexual risk-taking behavior and the factors associated with this behavior among heterosexual male university students in Turkey. While some of our findings are consistent 
with the HIV/AIDS risk-taking literature and the theoretical perspectives used in the study, some are not. These findings obtained as a result of the study are discussed below.

We have not found any relationship between religiosity and sexual risktaking behavior. It may be due to the religiosity scale used in this study that did not measure concept in two-dimensionally as internal and external religiosity. On the other hand, there is no consensus among researchers about how to measure religiosity (Kiylıoglu, 2014: 213). Another problem with measure of religiosity is that religious behavior may vary from culture to culture. One another explanation for this finding is that religiosity in Turkish culture may be independent from risky sexual behavior. According to social-cultural perspective, there is usually a negative correlation between religiosity and sexual risk-taking. Some studies carried out in Western countries supported this perspective. In a study conducted in the USA, religious behavior was found to be negatively associated with sexual risk-taking and other risk-taking behaviors (Kirk \& Levis, 2013: 1030). In another study in the USA, religiosity was consistently and negatively correlated to risk-taking behavior among Muslim, Christian, and Jewish university students (Berry et al., 2013: 695). Similarly, it was shown that religious beliefs correlate negatively with alcohol use and sexual risk among university students (Moore et al., 2013: 938). However our findings were not confirmed this expectation; theories explaining the sexual risktaking in terms of social-cultural perspectives were not supported. We wanted to compare this finding with similar studies in Turkey, but this did not happen due to the lack of similar research in Turkey. In addition to religiosity and risk-taking, studies are needed on the relationship between religiosity and sexuality in the country.

It was found positive correlation between sexual sensation seeking level and sexual risk-taking behavior. The findings supported Zuckerman's (2007) views on premarital sensation seeking theory. Kalichman and Romba (1995) also found similar significant relationship between risky sexual behavior and sexual sensation seeking level. The result is consistent with other findings in the literature on sexual sensation seeking (Gullette \& Lyons, 2006; Nguyen et al., 2012: 1237). However, different from Kalichman and Romba's findings, we have not found significant relationship between condom use status and sexual sensation seeking level. As personality traits are usually resistant to change, in health programs aimed at reducing risky sexual behavior of the high sensation seekers, success rate may be lower. Therefore, it could be useful to measure sexual sensation seeking level of program participants. There is a need for 
programs for young people who have a high level of sensation seeking to meet these needs in less risky ways, without endangering their lives.

According to cognitive decision making model, decision making is always rational and planned behavior. Accordingly, individuals who have adequate information about HIV transmission will take the necessary measures to keep away from such risky sexual behavior. In this study we have not found any relationship between HIV/AIDS knowledge and risky sexual behavior. The findings are not intended to support cognitive decision making model. Participants' level of information about HIV transmission was not prevented them from sexual risk-taking behavior. This result is consistent with findings of another study on Turkish university students (Özdemir et al., 2006: 15), and risky sexual behavior of female sex workers in Turkey (Bedük et al., 2011: 526). However, inconsistencies have been identified among studies conducted in Western and African countries. Some studies found correlation between HIV knowledge and risky sexual behavior (Snelling et al., 2006: 421), others found no association between the two variables (Mullings et al., 2004: 73). Risky sexual behaviors of the young adults appear to be independent from the level of knowledge about the routes of HIV transmission. This situation makes HIV awareness creation programs controversial by means of giving individual detailed information about HIV infection. This result may also raise questions about the effectiveness of information programs that are frequently applied in public health programs in Turkey. The effectiveness of these public health awareness programs should be regularly measured in the country.

According to social-cultural approach, masculine cultural characteristics such as courage determine the strength and position of men in society. On the other hand, attribution of passive cultural characteristics to women put the women in lower social position (Stewart and McDermott, 2004). As a result, it is expected to take more risk from men, and men's risky behavior is accepted by society. Our findings from the study also supported the social-cultural perspective. As masculinity level of the participants increase, their sexual risk-taking levels tend to increase. This result is consistent with the literature reporting that masculine gender role is associated with more risk-taking behavior (Garfield et al., 2008: 476; Harrison et al., 2006; O'Sullivan et al., 2006). In our study, it was detected that femininity predict risky sexual behavior negatively, conversely masculinity predict positively.

Although Turkey is a synthesis of different cultural structures, generally it is a patriarchal society (Koca et al., 2005). Masculine gender roles that have an effect of predicting HIV and other risky behaviors could be an 
important issue for societies adopted the traditional gender roles. As Bem's (1974: 161) noted, androgenity is the most favorable gender role for the integration of individuals in the society. Therefore, a transformation in the attitudes and behaviors of Turkish society is necessary, and it should be aimed at a transformation in Turkish men more than Turkish women.

In self-efficacy for AIDS prevention, only self-efficacy to use condoms has been shown to contribute to explain the risky sexual behavior. On the other hand, as self-efficacy to use condom increases, the likelihood of condom use at first intercourse also increase. As a result, condom use at first intercourse and condom use self-efficacy has been understood to be protective against risky sexual behavior. Through condom use selfefficacy, young adults can strengthen their belief about keeping and using condoms continuously, see themselves sufficient for coping with sexual risk, as a result they take less risk. The findings are consistent with Bandura's perceived self-efficacy theory (Bandura, 1977). As participants' self-efficacy for AIDS prevention increase, especially condom use selfefficacy, the higher will be the probability of abstinence from sexual risk. On the other hand, this outcome is also consistent with other studies which concluded that condom uses self-efficacy protect against sexual risk-taking (Casey et al., 2009: 66; Coleman \& Ball, 2009; French \& Holland, 2013: 56). In preventive health work in Western societies, individuals are made aware of condom use to increase their self-efficacy. The findings indicate that such awareness training should begin before the first sexual intercourse of youngsters.

Among demographic variables, the most remarkable ones for predicting risky sexual behavior are age, testing for HIV, and using condom at first intercourse. Age of participants is associated with greater sexual risktaking behavior. It is likely that heterosexual young men want to gain more sexual experience or try to explore their own sexuality as they get older and may take risks as a result. Participants who had tested for HIV took higher sexual risk scores. Probably, participants who aware of their risky sexual behavior wanted to know their latest HIV status through testing. Despite the fact that a significant proportion of respondents took sexual risk, only a small part of them had tested for HIV. This situation is a risk factor in itself. This low rate of HIV testing could be due to "nothing happens to me" misbelief which is common among adolescents and young adults worldwide. Individuals who are aware of their HIV infection status can prolong their life by drug treatment, and prevent infection of the disease to others by safe sexual behavior. Persons testing for HIV status are more concerned about their own health situation. Preventive intervention studies for those persons could be successful. Another 
important finding among demographic variable is that participants using condoms at first intercourse took less sexual risk. One of the most vital components of the campaign against risky sexual behavior in Western societies is teaching the habit of condom use regularly from adolescence onwards. This finding could once more prove protective effect of lifelong condom use. In liberal countries such as Turkey, it should be taught in educational institutions from an early age that condoms should be used regularly in sexual relations to prevent infections.

Although we used many variables to predict risky sexuality consistent with the frequently cited variables in HIV/AIDS sexual risk research, some variables were not found to be associated or weakly correlated with risky sexual behavior of the participants. These low correlations between variables may indicate the existence of other psychological or social variables that have the potential to predict risky sexual behaviors among heterosexual male Turkish university students. This situation also suggests that some variables specific to Turkish culture not included in this study may also predict risky sexuality among youngsters. As the risk of sexually transmitted infections is anticipated to continue, future studies should focus on uncovering other psychological and social variables in order to better reveal the risky sexual behaviors of Turkish university students and other youth groups.

\section{Limitations}

As participants, only heterosexual male college students were included in this study. In other words, other age groups, gender and sexual orientations has not been studied. Therefore similar studies should be done on heterosexual women, gay men and women among adolescents and young adults. The study was carried out on students at Ankara, and data from small and medium-sized cities has not been collected. Differences could exist between small and large settlements in the context of sexuality and risky sexual behavior in Turkey.

In the study, as in many other studies related to sexual behavior, data were collected by self-report of the participants. However, the data collected by self-report methods are likely to be affected with the social desirability. Although there have been significant changes in favor of women in the Republican era, male dominance still continue in Turkish society, and consequently men could exaggerate their sexual relationships. On the other hand, due to legal concern respondents may have hidden their consumption of illegal drugs before or during sexual intercourse. 


\section{References}

Acaroğlu, R. (2007). Knowledge and Attitudes of Mariners about AIDS in Turkey. Journal of the Association of Nurses in AIDS Care, 18, p. 48-55.

Ajayi, A.I. \& Olamijuwon, E.O. (2019). What Predicts Self-Efficacy? Understanding the Role of Sociodemographic, Behavioral and Parental Factors on Condom Use Self-Efficacy among University Students in Nigeria. Plos One, 14(8), p. 1-19.

Avcıkurt, A.S. (2014). Balıkesir Üniversitesi Öğrencilerinin HIV/AIDS Hakkındaki Bilgi Düzeyi ve Tutumlarının Değerlendirilmesi. Balıkesir Să̆lık Bilimleri Dergisi, 3(2), p. 79-86.

Bandura, A. (1977). Self-efficacy: Toward a Unifying Theory of Behavioral Change. Psychological Review, 84(2), 191-215.

Bedük, T., Ünlü, H. \& Duyan, V. (2011). AIDS Knowledge and Risky Sexual Behaviors among Registered Sex Workers in Turkey. Turkish Journal of Medical Science, 41(3), 521-531.

Bem, S.L. (1974). The Measurement of Psychological Androgyny. Journal of Consulting and Clinical Psychology, 42 (2), p. 155-162.

Berry, D., Bass, C.P., Shimp-Fassler, C. \& Succop, P. (2013). Risk, Religiosity, and Emerging Adulthood: Description of Christian, Jewish, and Muslim University Students at Entering the Freshmen Year. Mental Health, Religion \& Culture, 16(7), 695-710.

Bulduk, S. \& Erdoğan, S. (2008). Reliability and Validity of a SelfEfficacy Scale for AIDS Prevention among Turkish University Students. International Journal of Human Sciences, 5, p. 1-17.

Bulduk, S. (2009). Gençlerde Okula Dayalı Akran Eğitimi Girişimlerinin HIV/AIDS Risk Davranışlarını Azaltma Üzerine Etkisi (Doktora Tezi, İstanbul Üniversitesi, Sağlık Bilimleri Enstitüsü), İstanbul.

Carey, M.P., \& Schroder, K.E.E. (2002). Development and Psychometric Evaluation of the Brief HIV Knowledge Questionnaire (HIV-KQ18). AIDS Education \& Prevention. 14, p. 174- 184.

Casey, M.K., Timmermann, L., Allen, M., Krahn, S. \& Turkiewicz, K.L. (2009). Response and Self-Efficacy of Condom Use: A MetaAnalysis of this Important Element of AIDS Education and Prevention. Southern Communication Journal, 74, p. 57-78. 
Coleman, C.L. \& Ball, K. (2009). Predictors of Self-Efficacy to Use Condoms among Seropositive Middle-Aged African American Men. Western journal of Nursing Research, 31, p. 889-904.

Cooper, M.L. (2002). Alcohol Use and Risky Sexual Behavior among College Students and Youth. Journal of Studies on Alcohol, 14, p. 101-117.

Dökmen, Z.Y. (1999). Bem Cinsiyet Rolü Envanteri Kadınsılık ve Erkeksilik Ölçekleri Türkçe Formunun Psikometrik Özellikleri. Kriz Dergisi, 7 (1), p. 27-40.

French, S.E. \& Holland, K.J. (2013). Condom Negotiation Strategies as a Mediator of the Relationship between Self-Efficacy and Condom Use. Journal of Sex Research, 50, p. 48-59.

Gallagher, M.W. (2012). Self-Efficacy. In V.S. Ramachandran (Ed.). Encyclopedia of Human Behavior, p. 315-320, London: Academic Press.

Garfield, C.F., Isacco, A. \& Rogers, T.E. (2008). A Review of Men's Health and Masculinity. American Journal of Lifestyle Medicine, 2(6), 474-487.

Gullette, D.L. \& Lyons, M.A. (2006). Sensation Seeking, Self-Esteem, and Unprotected Sex in College Students. Journal of the Association of Nurses in AIDS Care, 17(5), 23-31.

Harrison, A., O’Sullivan, L.F., Hoffman, S., Dolezal, C. \& Morrell, R. (2006). Gender Role and Relationship Norms among Young Adults in South Africa: Measuring the Context of Masculinity and HIV Risk. Journal of Urban Health, 83(4), p. 709-722.

Kalichman, S.C. \& Rompa, D. (1995). Sexual Sensation Seeking and Sexual Compulsivity Scales: Reliability, Validity, and Predicting HIV Risk Behavior. Journal of Personality Assessment, 65 (3), p. 586-601.

Kavuncu, N. (1987). Bem Cinsiyet Rolü Envanteri'nin Türk Toplumuna Uyarlama Çalışması. (Yüksek Lisans Tezi, Hacettepe Üniversitesi, Sosyal Bilimler Enstitüsü), Ankara.

Kıylığlu, L. \& Dönmez, A. (2016). HIV/AIDS'e Yol Açan Riskli Cinsel Davranışla İlişkili Psikososyal ve Kültürel Etmenler. Psikiyatride Güncel Yaklaşımlar, 8(4), p. 367-379.

Kıylığlu, L. \& Dönmez, A. (2017). HIV/AIDS Riskini Artıran Cinsel Davranışlar. Psikiyatride Güncel Yaklaşımlar, 9(2), p. 147-162. 
Kıylığlu, L. (2013). Cinsel Heyecan Arama Ölçeği (CHAÖ): Türkçeye Uyarlama, Geçerlik ve Güvenirlik Çalışması. Ankara Sağllk Bilimleri Dergisi, 2013 (2), p. 41-55.

Kıylığlu, L. (2014). Batı Toplumlarında Dindarlık ve Cinsel Risk Alma Arasındaki İlişki Üzerine Bir Derleme. Ankara Üniversitesi İlahiyat Fakültesi Dergisi, 55 (2), p. 195-218.

Kirk, C.M. \& Lewis, R.K. (2013). The Impact of Religious Behaviors on the Health and Well-Being of Emerging Adults. Mental Health, Religion \& Culture, 16(10), 1030-1043.

Koca, C., Asçı, F.H. \& Kirazcı, S. (2005). Gender Role Orientation of Athletes and Nonathletes in a Patriarchal Society: A Study in Turkey. Sex Roles, 52, p. 217-225.

Landor, A., Simons, L.G., Simons, R.L., Brody, G.H. \& Gibbons, F.X. (2011). The Role of Religiosity in the Relationship between Parents, Peers, and Adolescent Risky Sexual Behavior. Journal of Youth and Adolescence, 40, p. 296-309.

Lee, Y.H., Salman, A. \& Fitzpatrick, J.J. (2009). Preventive Self-Efficacy, Depressive Symptoms, and Risky Sexual Behaviors in Adolescents: A Cross-Sectional Questionnaire Survey. International Journal of Nursing Studies, 46, p. 653-660.

Leigh, B.C. \& Stall, R. (1993). Substance Use and Risky Sexual Behavior for Exposure to HIV: Issues in Methodology, Interpretation, and Prevention. American Psychologist, 48(10), p. 1035-1045.

Lopez, F. \& Rubia, J.M. (2001). Validation of a Self-Efficacy Scale for AIDS Prevention among Adolescents. Salud Pública de México, 43 (5), p. 421-432.

Manlove, J., Logan, C., Moore, K.A. \& Ikramullah, E. (2008). Pathways from Family Religiosity to Adolescent Sexual Activity and Contraceptive Use. Perspectives on Sexual and Reproductive Health, 40(2), p. 105-117.

Moore, E.W., Berkley-Patton, J.Y. \& Hawes, S. M. (2013). Religiosity, Alcohol Use, and Sexual Behaviors among College StudentsAthletes. Journal of Religion and Health, 52, p. 930-940.

Mullings, J.L., Marquart, J.W. Carr, T. \& Hartley, D.J. (2004). Knowledge is not Always Power: HIV Risk Behavior and the Perception of Risk among Women Prisoners. Journal of Correctional Health Care, 11, p. 59-78. 
Neymotin, F. \& Downing-Matibag, T.M. (2013). Religiosity and Adolescents' Involvement with Both Drugs and Sex. Journal of Religion and Health, 52, p. 550-569.

Nguyen, H.V., Koo, K.H., Davis, K.C., Otto, J.M., Handershot, C.S., Schacht, R.L., George, W.H., Heiman, J.R. \& Norris, J. (2012). Risky Sex: Interactions among Ethnicity, Sexual Sensation Seeking, Sexual Inhibition, and Sexual Excitation. Archives of Sexual Behavior, 41, p. 1231-1239.

Norton, T.R., Bogart, L.M., Cecil, H. \& Pinkerton, S.D. (2005). Primacy of Affect Over Cognition in Determining Adult Men's Condom-Use Behavior: A Review. Journal of Applied Social Psychology, 12, p. 2493-2534.

O’Sullivan, L.F., Hoffman, S., Harrison, A. \& Dolezal, C. (2006). Men, Multiple Sexual Partners, and Young Adults' Sexual Relationships: Understanding the Role of Gender in the Study of Risk. Journal of Urban Health, 83(4), p. 695-708.

Ok, Ü. (2011). Dini Tutum Ölçeği: Geliştirme ve Geçerlik Çalışması. Uluslararası İnsan Bilimleri Dergisi, 8 (2), p. 528-549.

Öngen, D.E. (2007). The Relationships between Sensation Seeking and Gender Role Orientations among Turkish University Students. Sex Roles, 57, p. 111-118.

Özdemir, M., Feyzioğlu, B., Doğan, M., Maykan, M. \& Baysal, B. (2006). Üniversite Öğrencilerinin HIV/AIDS Hakkındaki Bilgi Düzeyi ve Tutumlarının Değerlendirilmesi. Türk HIV/AIDS Dergisi, 9, p. 1016.

Patricio, A.C.F.A., Bezerra, V.P., Nogueira, J.A., Moreira, M.A.S.P., Camargo, B.V. \& Santos, J.S. (2019). Knowledge of Sex Workers about HIV/AIDS and its Influence on Sexual Practices. Revista Brasileira de Enfermagem, 72(5), p. 1310-1317.

Reidy, D.E., Brookmeyer, K.A., Gentile, B., Berke, D.S. \& Zeichner, A. (2016). Gender Role Discrepancy Stress, High-Risk Sexual Behavior, and Sexually Transmitted Disease. Archives of Sexual Behavior, 45, p. 459-465.

Siyez, D.M. \& Siyez, E. (2009). Üniversite Öğrencilerinin Cinsel Yolla Bulaşan Hastalıklara İlişkin Bilgi Düzeylerinin İncelenmesi. Türk Üroloji Dergisi, 35(1), p. 49-55. 
Snelling, D., Omariba, D.W.R., Hong, S., Georgiades, K., Racine, Y. \& Boyle, M.H. (2006). HIV/AIDS Knowledge, Women's Education, Epidemic Severity and Protective Sexual Behavior in Low and Middle-Income Countries. Journal of Biosocial Science, 39, p. 421442 .

Stewart, A.J. \& McDermott, C. (2004). Genders in Psychology. Annual Review of Psychology, 55, p. 519-544.

Stulhofer, A., Graham, C.A., Bozicevic, I., Kufrin, K., \& Ajdukovic, A. (2009). An Assessment of HIV/STI Vulnerability and Related Sexual Risk-Taking in a Nationally Representative Sample of Young Croatian Adults. Archives of Sexual Behavior, 38, p. 209225.

The Ministry of Health of Turkey, World AIDS Day, 2019 (retrieved from https,://hsgm.saglik.gov.tr/news, 28.07.2020).

Vygotsky, L.S. (1978). Mind in society: The Development of higher Psychological Processes, Harvard: Harvard University Press.

Yau, S., Wongsawat, P. \& Songthap, A. (2020). Knowledge, Attitude, and Perception of Risk and Preventive Behaviors toward Premarital Sexual Practice among In-School Adolescents. European Journal of Investigation in Health, Psychology and Education, 10, p. 497-510.

Zuckerman, M. (2007). Sensation Seeking and Risky Sexual Behavior, Washington: American Psychological Association. 